\title{
Erratum to: An ecological study of sand flies (Diptera: Psychodidae) in the vicinity of Lençóis Maranhenses National Park, Maranhão, Brazil
}

Adalberto Alves Pereira Filho ${ }^{1 *}$, Maria da Conceição Abreu Bandeira², Raquel Silva Fonteles ${ }^{2}$, Jorge Luiz Pinto Moraes², Camila Ragonezi Gomes Lopes ${ }^{3}$, Maria Norma Melo ${ }^{1}$ and José Manuel Macário Rebêlo²

Unfortunately, the original version of this article [1] contained a mistake. In Figure 1, panels C and D were inadvertently included as duplicates of panel $\mathrm{B}$. The correct Figure 1, with the correct panels $\mathrm{C}$ and $\mathrm{D}$ is included below.

\section{Author details}

'Departamento de Parasitologia, Instituto de Ciências Biológicas,

Universidade Federal de Minas Gerais, Belo Horizonte 31270-901, MG, Brazil.

2Departamento de Biologia, Centro de Ciências Biológicas e da Saúde,

Universidade Federal do Maranhão, São Luís 65080-805, MA, Brazil.

${ }^{3}$ Departamento de Cartografia, Instituto de Geociências, Universidade Federal

de Minas Gerais, Belo Horizonte 31270-901, MG, Brazil.

Received: 9 November 2015 Accepted: 9 November 2015

Published online: 20 November 2015

\section{Reference}

1. Pereira Filho AA, Bandeira Mda C, Fonteles RS, Moraes JL, Lopes CR,

Melo MN, et al. An ecological study of sand flies (Diptera: Psychodidae)

in the vicinity of Lençóis Maranhenses National Park, Maranhão, Brazil.

Parasites \& Vectors. 2015:8:442.

\footnotetext{
* Correspondence: magneto_pa@hotmail.com

'Departamento de Parasitologia, Instituto de Ciências Biológicas,

Universidade Federal de Minas Gerais, Belo Horizonte 31270-901, MG, Brazil
}

Full list of author information is available at the end of the article

Submit your next manuscript to BioMed Central and take full advantage of:

- Convenient online submission

- Thorough peer review

- No space constraints or color figure charges

- Immediate publication on acceptance

- Inclusion in PubMed, CAS, Scopus and Google Scholar

- Research which is freely available for redistribution 


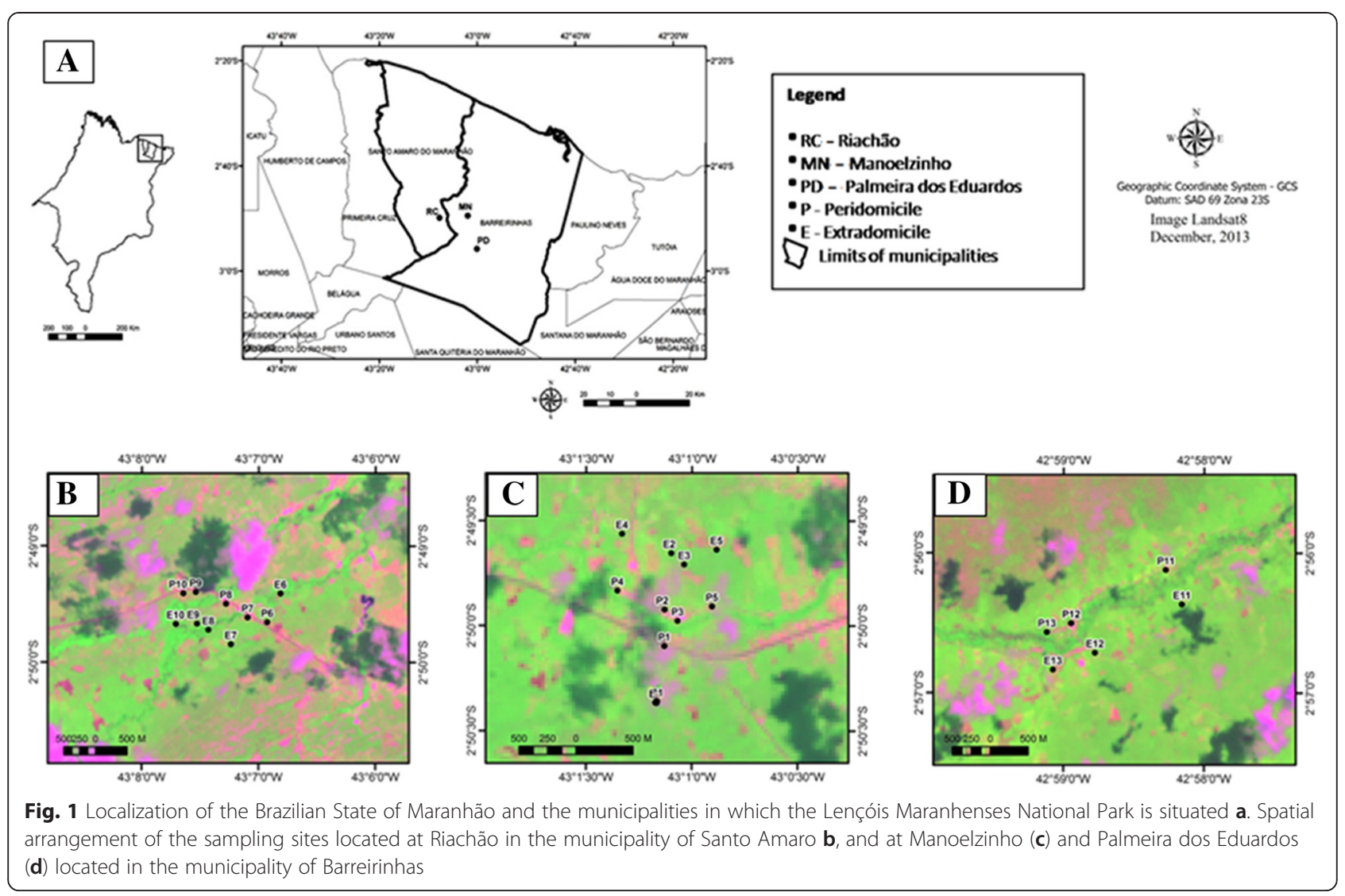

